Research Journal of Environmental and Earth Sciences 10(1): 24-33, 2018

DOI:10.19026/rjees. 10.5864

ISSN: 2041-0484; e-ISSN: 2041-0492

(C) 2018 Maxwell Scientific Publication Corp.

$\begin{array}{lll}\text { Submitted: October 20, } 2017 & \text { Accepted: December 30, } 2017 & \text { Published: May 20, } 2018\end{array}$

\title{
Research Article 3D Spatial Distribution of Reservoir Parameters for Prospect Identification in "Bizzy" Field, Niger Delta
}

\author{
S.J. Abe, M.A. Ayuk, K. Mogaji and O.O. Kafisanwo \\ Department of Applied Geophysics, Federal University of Technology Akure, Nigeria
}

\begin{abstract}
This study focuses on the use of some geostatistical tools to spatially distribute reservoir parameters in order to identify the bypassed prospects from the earlier seismic interpretation that was carried out in the field using 3D seismic data. Four wells and seismic data were used to generate the interpreted input horizon grids, fault polygons and to carry out detailed petrophysical analysis. Structural and property modeling which include; facies, net to gross, porosity and water saturation were distributed stochastically within the constructed 3D grid using Sequential Gaussian Simulation (SGS) algorithm. The reservoir structural model show system of different oriented growth faults F1 to F9. Faults F1, F2, F3 and F4 were the major growth faults, dipping towards south-west and are quite extensive almost across all the seismic section. A rollover anticline formed as a result of deformation of the sediments deposited on the downthrown block of fault F1. The other faults were minor fault (synthetic and antithetic). The trapping mechanism is a fault assisted anticlinal closure. Results from well log analysis and petrophysical models shows Godwin reservoir to be a moderate to good reservoir in terms of facies, with good net to gross, porosity, permeability and low water saturation. This study has also demonstrated the effectiveness of 3D geostatical modeling technique as a tool for better understanding the distribution with respect to space of continuous reservoir properties. It will also provide a framework for the future prediction of reservoir qualities and yield rate of the reservoirs.
\end{abstract}

Keywords: Antithetic, deformation, geostatistics, porosity, stochastic, synthetic

\section{INTRODUCTION}

The key point is that 3-D models are three dimensional; they are built so that the interpreter can use spatial data in their correct relation to the data around them for visualization and for calculations, whereas statistical spreadsheet simulations deal with averaged input values and spatially detached data ( $\mathrm{Liz}$, 2009).

In reservoir modeling subject there are different methods for 3D reservoir modeling. In each of these methods using geological information, mathematical or statistical sciences and different software, properties of the reservoir are modeled. There are some publications in different aspects of the reservoir modeling such as dynamic reservoir simulations (Labourdette et al., 2006; Jackson et al., 2005), fracture intensity (Wong, 2003; Masaferro et al., 2003), 3D stratigraphy, 3D structural model (Mitra and Leslie, 2003; Mitra et al., 2006; Hennings et al., 2000).

Geostatistical method is a powerful tool in modeling now. As a historical review the quantification of geology has always been a fascinating topic and of the first pioneering efforts may be noted those of
Vistelius (1992) and his many followers using Markov chain analysis (Ethier, 1975) to quantify onedimensional lithological sequences along well. Many successes were encountered with this approach, but it appeared difficult to generalize to the second and third dimension. Then, in the mid sixties, the giant Hassi Messaoud field in Algeria was the object of pioneering application of quantitative reservoir description techniques. The distribution of sand lenses and shale break was modeled in a vertical cross-section with the goal of understanding their impact on effective permeability. This model was used as a basis for reservoir simulation and it was observed that, because heterogeneities were modeled in a realistic way, a satisfactory history-match could be achieved more easily (Dubrule, 1998; Clevis et al., 2006). Three realizations are different; such a model often consists of hundreds of thousands of grid cells. Current reservoir simulators are not able to handle such large data set and scaling-up of heterogeneity models is required before they can be handled by flow simulators. These models will represent the spatial distribution of petrophysical parameters such as porosity and water saturation (Dubrule, 1998).

Corresponding Author: S.J. Abe, Department of Applied Geophysics, Federal University of Technology Akure, Nigeria This work is licensed under a Creative Commons Attribution 4.0 International License (URL: http://creativecommons.org/licenses/by/4.0/). 
Realistic 3D geological models are then re-quired as input to reservoir simulation programs which predict the movement of rocks under various hydrocarbon scenarios. An actual reservoir can only be developed and produced once and mistakes can be tragic and wasteful. It is essential to model the reservoir as accurately as possible in order to calculate the reserves and to determine the most effective way of recovering as much of the petroleum economically as possible (Lucia and Fogg, 1990; Lake et al., 1991; Worthington, 1991; Haldersen and Dasleth, 1993) hence, allows for 3D visualization of the subsurface, which enhances understanding of reservoir heterogeneities and helps to improve recovery rates, as low recovery rates stem from inefficient sweep caused by poor knowledge of inter well-scale heterogeneities (Patrick et al., 2002).

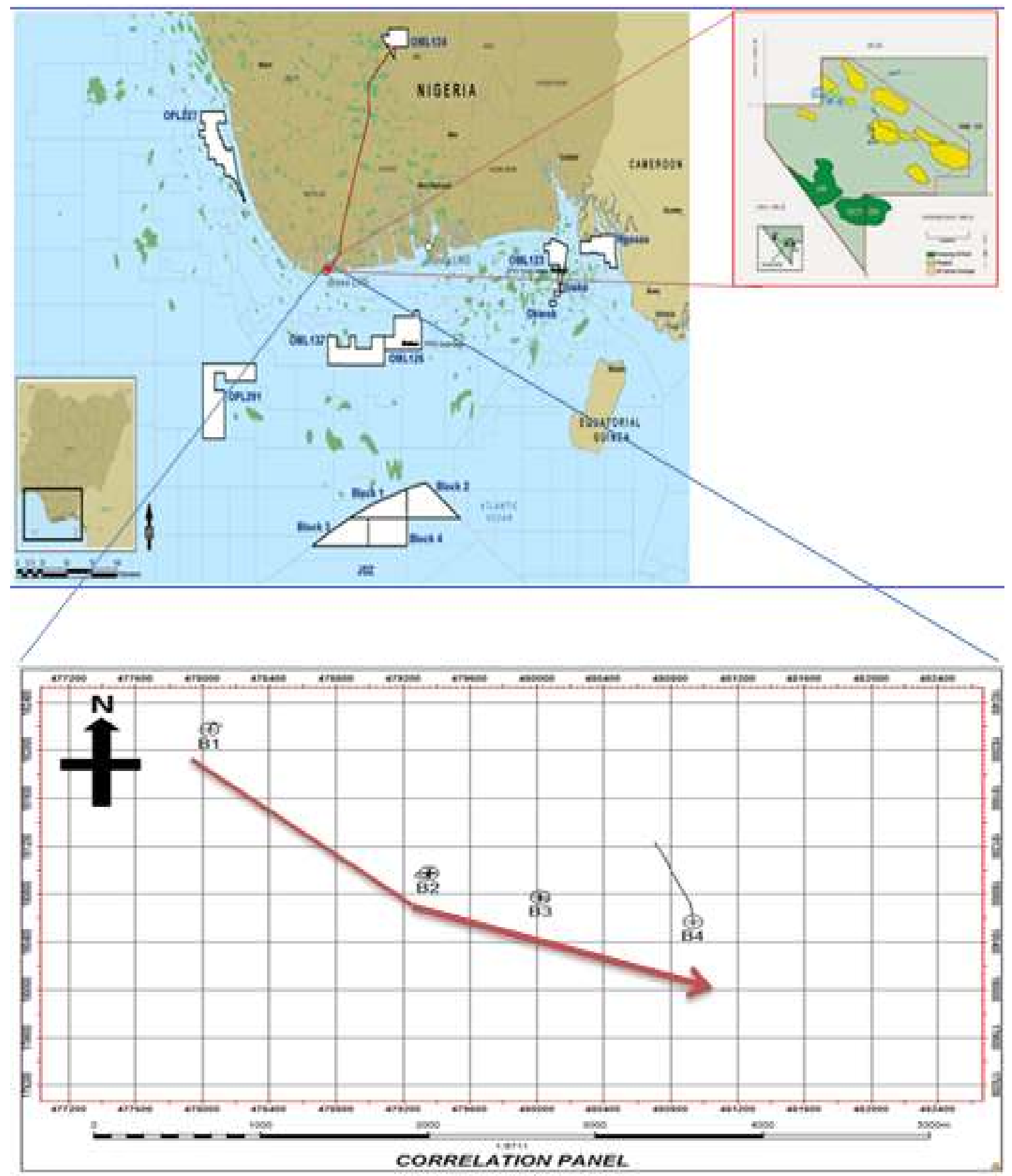

Fig. 1: Map of study area (BIZZY FIELD) 
The advances in computational technology, modern reservoir models can accommodate increasingly detailed 3D data that illustrate the spatial distribution of reservoir properties. Subsurface reservoir characterization typically incorporates well data augmented with seismic data to establish the geological model of the reservoir (Patrick et al., 2002).

This research '3D Spatial Distribution of Reservoir Parameters For Prospect Identification In "Bizzy" Field, Niger Delta'made use of petrophysical well log data within reservoirs using geostatical method across the reservoirs to have a better knowledge of the reservoir quality for the recommendation of possible location for drilling of developmental well(s) that will help to effectively extract the hydrocarbon in place for a long period of time.

\section{GEOLOGY OF STUDY AREA}

The study area BIZZY field is located onshore in the Niger Delta region of Nigeria (Fig. 1). The Niger Delta has being proved over recent years to be a prolific oil and gas province that is situated in the Gulf of Guinea in the West Coast of Central Africa.

The Niger Delta basin contains only one identified petroleum system referred to as the Tertiary Niger Delta Petroleum System. The Tertiary section of the Niger Delta is divided into three formations, Akata formation (potential source rockcomposed of thick shale sequences), Agbada formation (major petroleum bearing unitconsisting of paralicsili-clastics basically sandstone) and the Benin formation (poorly sorted, medium to fine grained sands and gravels with a few shale intercalations). These formations were deposited in marine, transitional and continental environments respectively; together they form a thick, overall progradational passive-margin wedge.

The major structural features in the Niger Delta are growth faults and roll-over anticlines (Evamy et al., 1978), most of the trapping system in this region is associated with simple rollover structure; clay filled channels structures with multiple growth faults, antithetic faults and collapsed crest structures.

Workflow of the research work: The workflow that was used to carry out this research is as shown in the Fig. 2. It runs from the loading of data, well log interpretation, seismic to well tie, seismic interpretation and finally generation of geological models of the delineated reservoir.

The data available (i.e., well data and seismic data) were loaded and litho-stratigraphic correlation was done using the gamma ray log to differentiate between the two major formation units (i.e., sand and shale), resistivity log was used to differentiate between formation water and hydrocarbon and the neutron density crossover was further utilized to differentiate the type of hydrocarbon present after which prospective reservoirs were delineated and petrophysical analysis of the reservoir units were evaluated. Synthetic seismogram was generated using density and sonic log and well to seismic tie was carried out to generate a relationship between seismic and well with checkshot data identifying the event of the well tops. The event from the seismic to well tie is then picked as horizon across the seismic volume (i.e., inlines and crosslines). The picked horizon are then interpolated to generate time structural maps which are later converted to depth

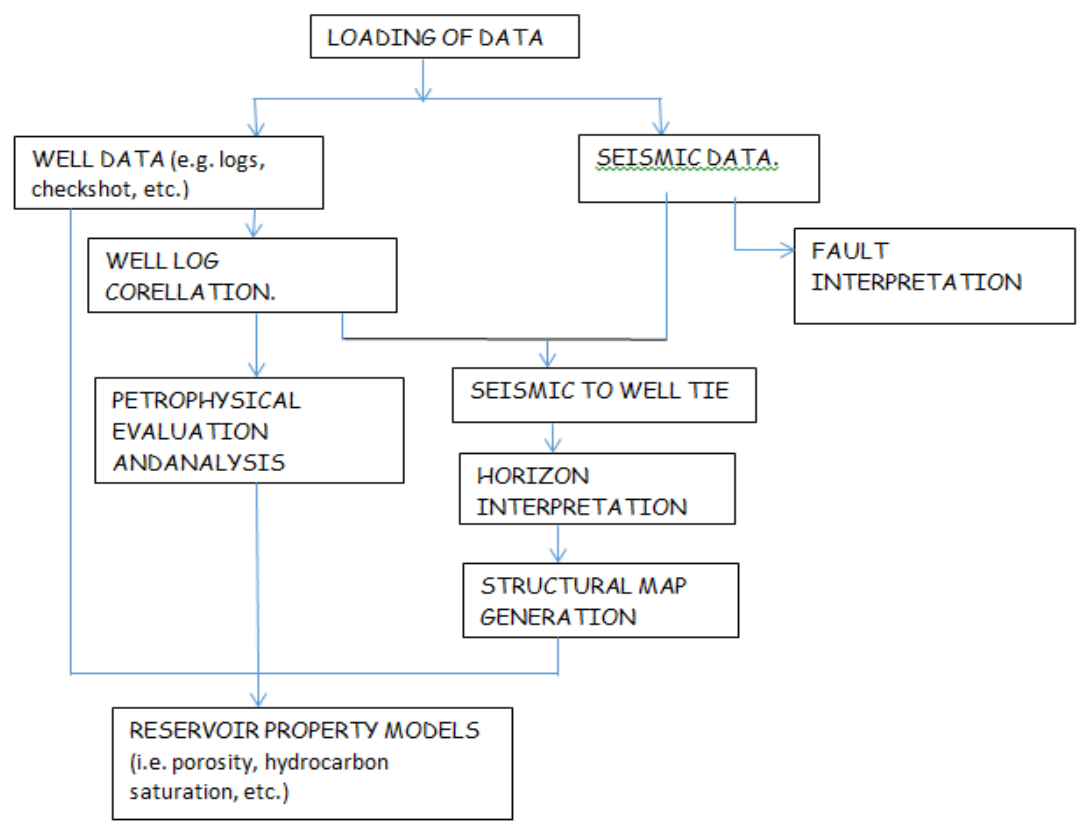

Fig. 2: A diagram showing the workflow followed during the research 


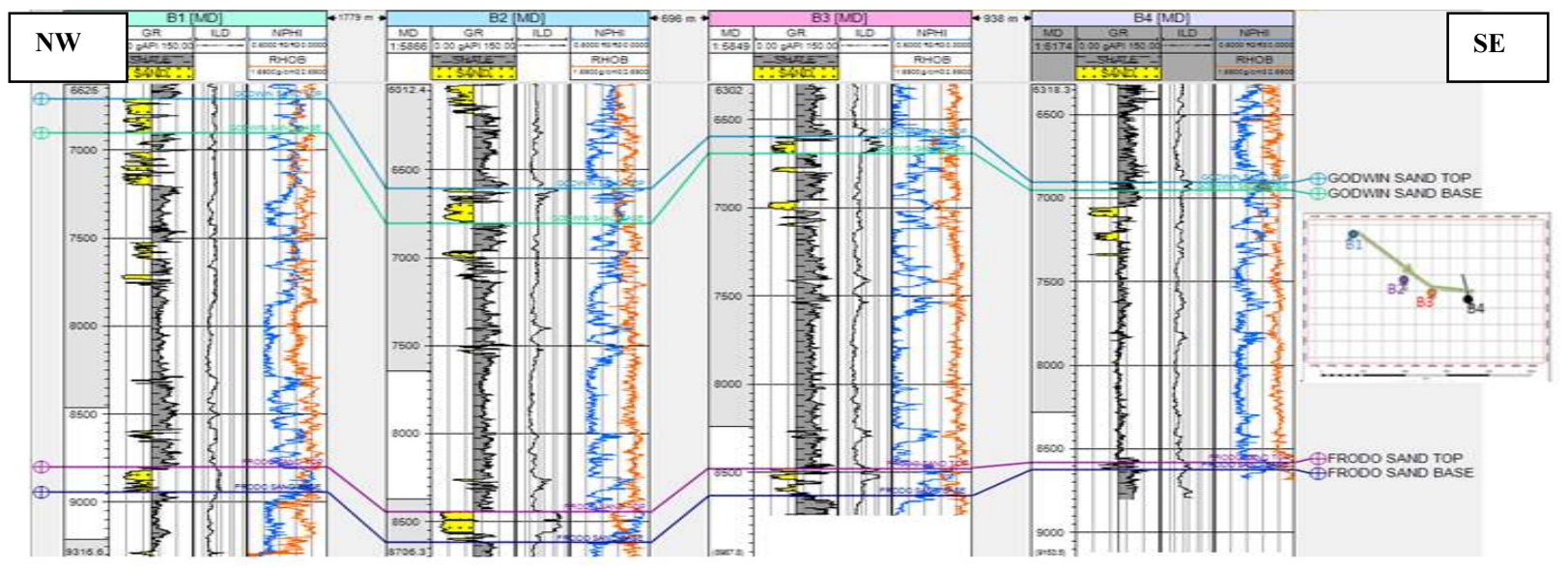

Fig. 3: Lithostratigraphic correlation of well logs through B1, B2, B3 and B4 in NE-SW direction

Table 1: Petrophysical evaluation (a) Godwin reservoir

\begin{tabular}{llllllll}
\hline Wells & Top & Base & $\begin{array}{l}\text { Gross } \\
\text { thickness }(\mathrm{ft})\end{array}$ & $\begin{array}{l}\text { Net thickness } \\
(\mathrm{ft})\end{array}$ & NPAY (ft) & NTG (\%) & VSH (\%) \\
\hline B1 & 6707.61 & 6900.35 & 193.37 & 174.92 & & 90 & 18 \\
B2 & 6608.05 & 6806.03 & 197.66 & 164.65 & 32.25 & 83 & 21 \\
B3 & 6597.22 & 6691.30 & 93.27 & 80.64 & 46.4 & 87 & 6 \\
B4 & 6900.16 & 6958.78 & 51.34 & 17.51 & & 34 & 15 \\
\hline Wells & $\varnothing \mathrm{T}(\%)$ & $\emptyset \mathrm{E}(\%)$ & Sw $(\%)$ & Sh $(\%)$ & BW $(\%)$ & K (mD) & \\
\hline B1 & 25 & 21 & 99 & 1 & 22 & 602.80 & \\
B2 & 26 & 21 & 81 & 19 & 21 & 610.50 & \\
B3 & 24 & 23 & 36 & 64 & 9 & 1265.6 & \\
B4 & 23 & 20 & 58 & 42 & 13 & 405.66 & \\
\hline
\end{tabular}

Table 1: Petrophysical evaluation (b) Frodo reservoir

\begin{tabular}{llllllll}
\hline WELLS & Top & Base & $\begin{array}{l}\text { Gross } \\
\text { thickness }(\mathrm{ft})\end{array}$ & $\begin{array}{l}\text { Net thickness } \\
(\mathrm{ft})\end{array}$ & NPAY (ft) & NTG (\%) & VSH (\%) \\
\hline B1 & 8798.57 & 8943.48 & 144.23 & 136.36 & & 94 & 9 \\
B2 & 8444.58 & 8819.71 & 170.36 & 145.95 & 109 & 86 & 7 \\
B3 & 8476.99 & 8634.93 & 159.31 & 94.72 & 44.6 & 60 & 15 \\
B4 & 8581.66 & 8624.39 & 33.08 & 17.71 & & 54 & 21 \\
\hline WELLS & $\varnothing \mathrm{T}(\%)$ & $\emptyset \mathrm{E}(\%)$ & Sw $(\%)$ & Sh $(\%)$ & BVW (\%) & K (mD) & \\
\hline B1 & 18 & 16 & 73 & 27 & 13 & 66.05 & \\
B2 & 27 & 25 & 40 & 60 & 11 & 2508 & \\
B3 & 23 & 20 & 59 & 41 & 41 & 408.12 & \\
B4 & 16 & 13 & 61 & 39 & 10 & 12.08 & \\
\hline
\end{tabular}

structural map using velocity model generated. The structural depth maps (i.e., top and base) was incorporated with petrophysical parameters from well logs creating a structural 3D grid which served as the basis for the petrophysical reservoir models.

\section{RESULTS AND DISCUSSION}

Well log correlation: Figure 3 below shows the lithographic correlation and the delineated reservoirs using gamma ray $\log$, resistivity $\log$ and neutron/density logs over well B1, B2, B3 and B4 in the NE-SW direction. Two reservoirs were mapped named "Godwin" and "Frodo" reservoirs respectively. The thickness of the two reservoirs looks appreciably uniform from the North-Western to the South-Eastern direction and the reservoirs also thins along the same direction.
Petrophysical analysis of the mapped reservoirs: The petrophysical evaluation and analysis of the two delineated reservoirs were presented as shown in Table 1. Based on the result shown in Table 1a, Godwin reservoir has an average thickness of approximately $134 \mathrm{ft}$, net sand thickness ranging from (18ft-175ft) and a net pay ranging from $(33 \mathrm{ft}-46 \mathrm{ft})$, average effective porosity ranging from $20 \%$ to $23 \%$ with highest permeability of $1265 \mathrm{mD}$ on well B3 and average hydrocarbon saturation ranging from (0.01\%-64\%) which can be used to infer that some pores present are being occupied by hydrocarbons. It can be seen from the chart in Fig. 4, that well B1 and B2 have the thickest delineated reservoir and they also have the highest sand thickness but well B3 is observed to have the highest net pay, a good net to gross, a reasonable effective porosity of about $23 \%$ with the highest hydrocarbon saturation which makes it the most promising well for the Godwin reservoir. 


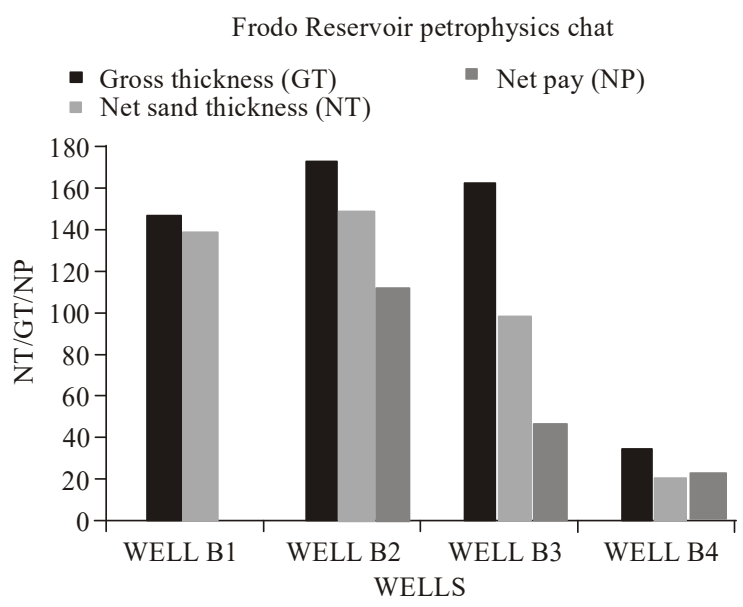

Frodo reservoir petrophysics chat

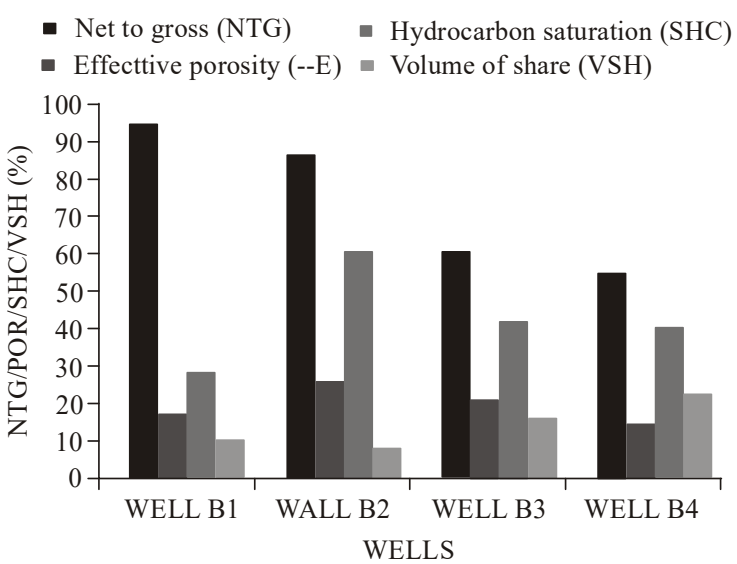

Fig. 4: Chart of reservoirs

The petrophysical analysis result obtained from Frodo reservoir is shown in Table $1 \mathrm{~b}$, it has an average thickness of approximately $127 \mathrm{ft}$, net sand thickness ranging from $(18 \mathrm{ft}-145 \mathrm{ft})$, average net pay ranging from (45ft-109ft) which means that reasonable part of the reservoir contain hydrocarbon and this makes it a little bit economical compared to the previous reservoir, effective porosity of the four wells penetrating the Frodo reservoir ranges from $13 \%$ to $25 \%$ which shows that there are reasonable amount of pore spaces to accommodate fluids and also the highest permeability was noticed on well B2 with average water saturation ranging from $40 \%-73 \%$. The petrophysical charts of reservoir showing the petrophysical variations on each well for Frodo reservoir can be seen Fig. 4. The chart shows that well B2 is the most promising well for effective extraction characterized by thickness of about $170 \mathrm{ft}$, a good net sand thickness of about 146ft, a reasonable net pay thickness of about 109ft, a net to gross of about $86 \%$, moderate porosity of about $27 \%$ and a high hydrocarbon saturation of about $60 \%$.

Structural map interpretation: Figure 5 shows the structural map of sand tops. The wells B1-B4 were
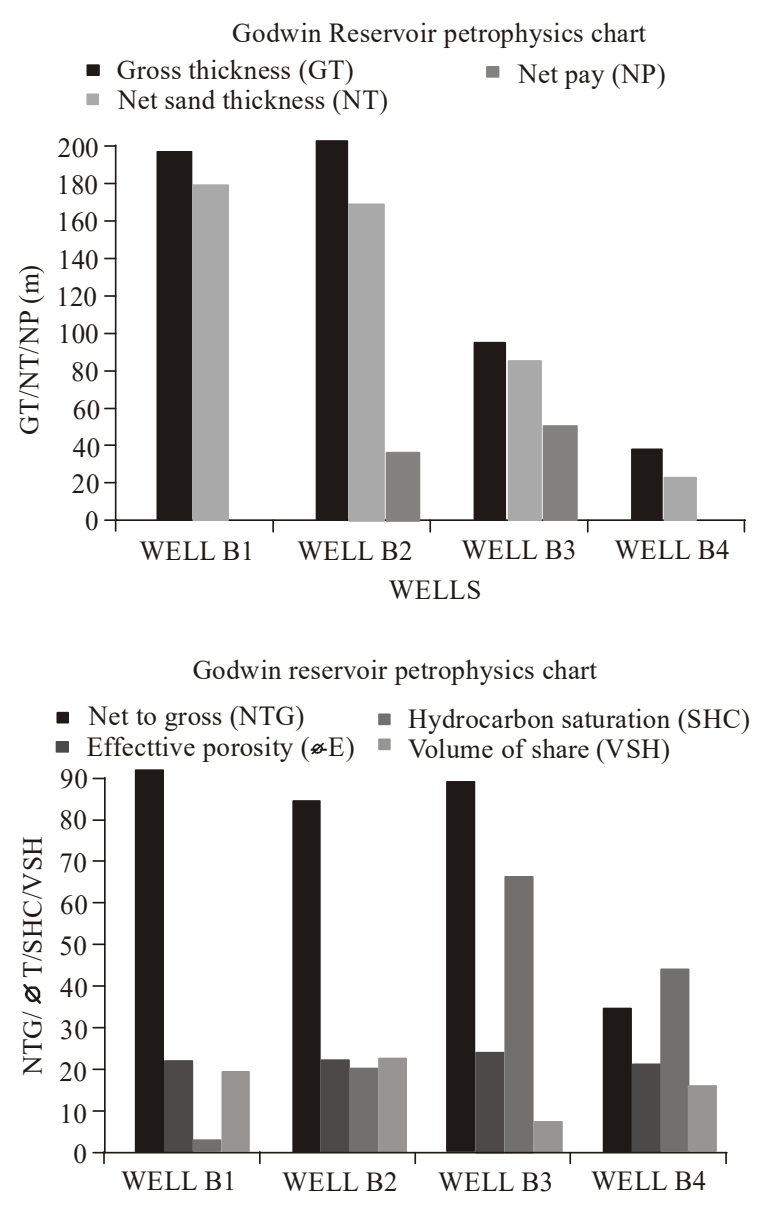

drilled at the flank of an anticlinal structure. Four major synthetic faults (F1, F2, F3 and F4) dipping southwards and trending from east to west were identified cutting across this surface with a minor fault at the northwestern part of the structural map. Figure 5a and $5 \mathrm{~b}$ shows fault assisted closure towards the central portion of the map with one of the major fault F1, an anticlinal structure bounded at both side by faults F2 and F3 trending from east to west were identified cutting across this surface with a minor fault at the northwestern part of the structural map. There is also a prospective structural high at the northeastern portion of the BIZZY field which might be a closure if validated by acquiring more data around the area. Figure $5 \mathrm{c}$ and $5 \mathrm{~d}$ shows an anticlinal structure towards the central portion of Frodo reservoir bounded by two major faults F2 and F3. Fault F4 also enhanced a two way fault assisted closure towards the southern portion of the map.

Geological model interpretation of godwin reservoir: Only Godwin reservoir was modelled to show the 3D spatial distribution of petrophysical parameters. The 3D perspective view of the facies model showing the variation and distribution of facies 
Res. J. Environ. Earth Sci., 10(1): 24-33, 2018
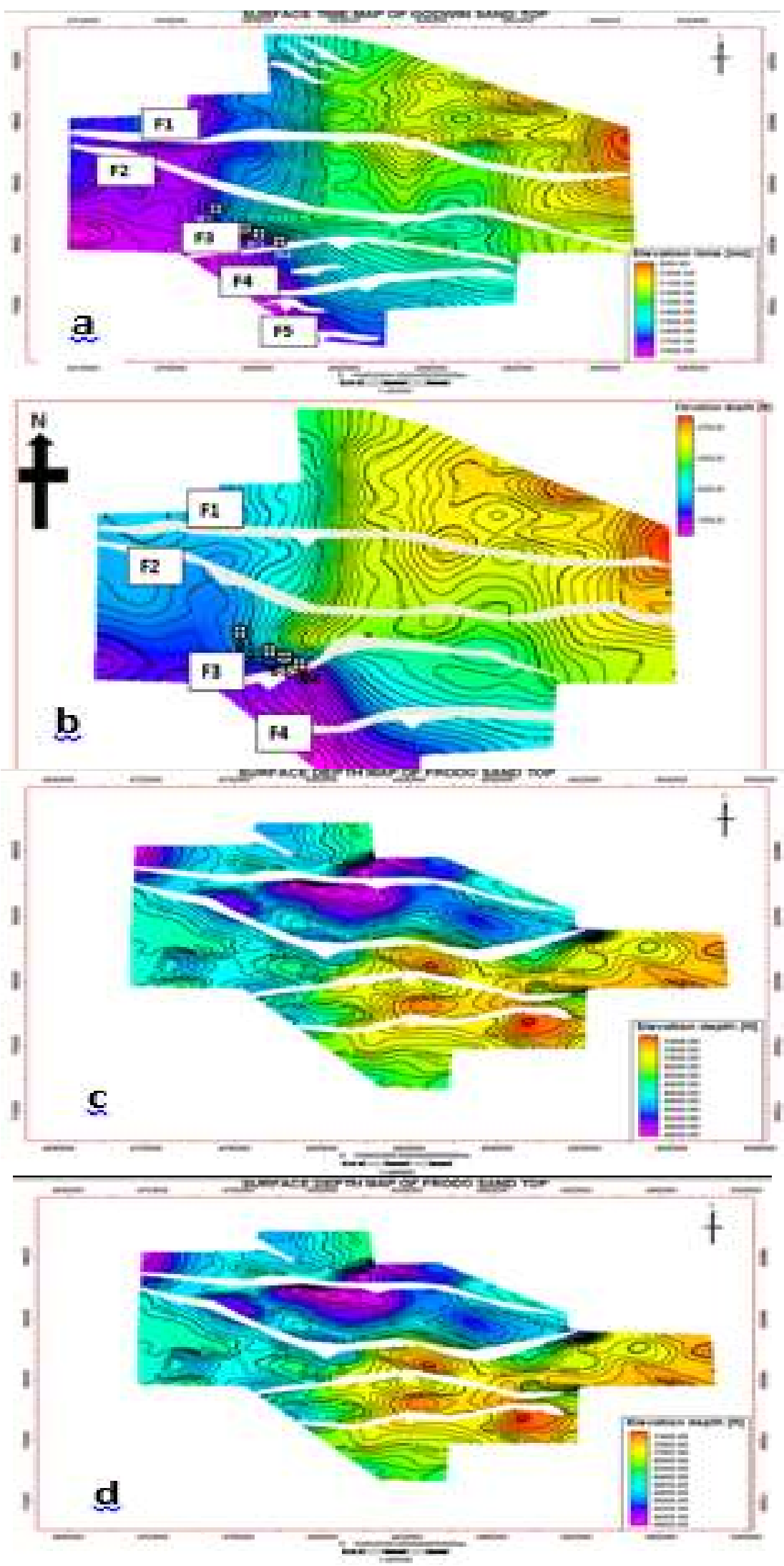

Fig. 5: Surface maps; (a): time map of Godwin sand top; (b): depth map of Godwin sand top; (c): time map of Frodo sand top; (d): depth map of Frodo sand top 


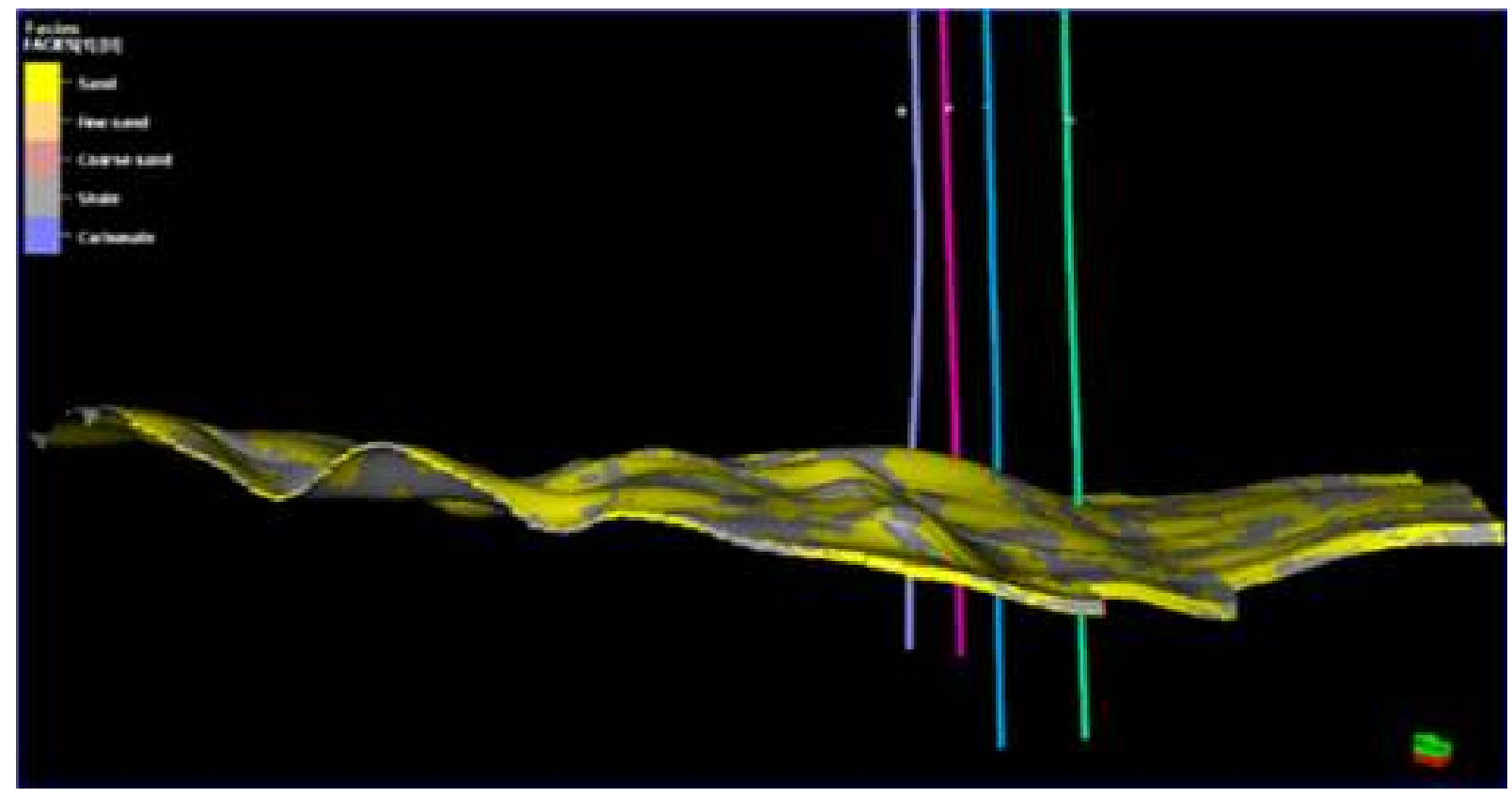

Fig. 6: Petrophysical model of Godwin reservoir (Facies Model)

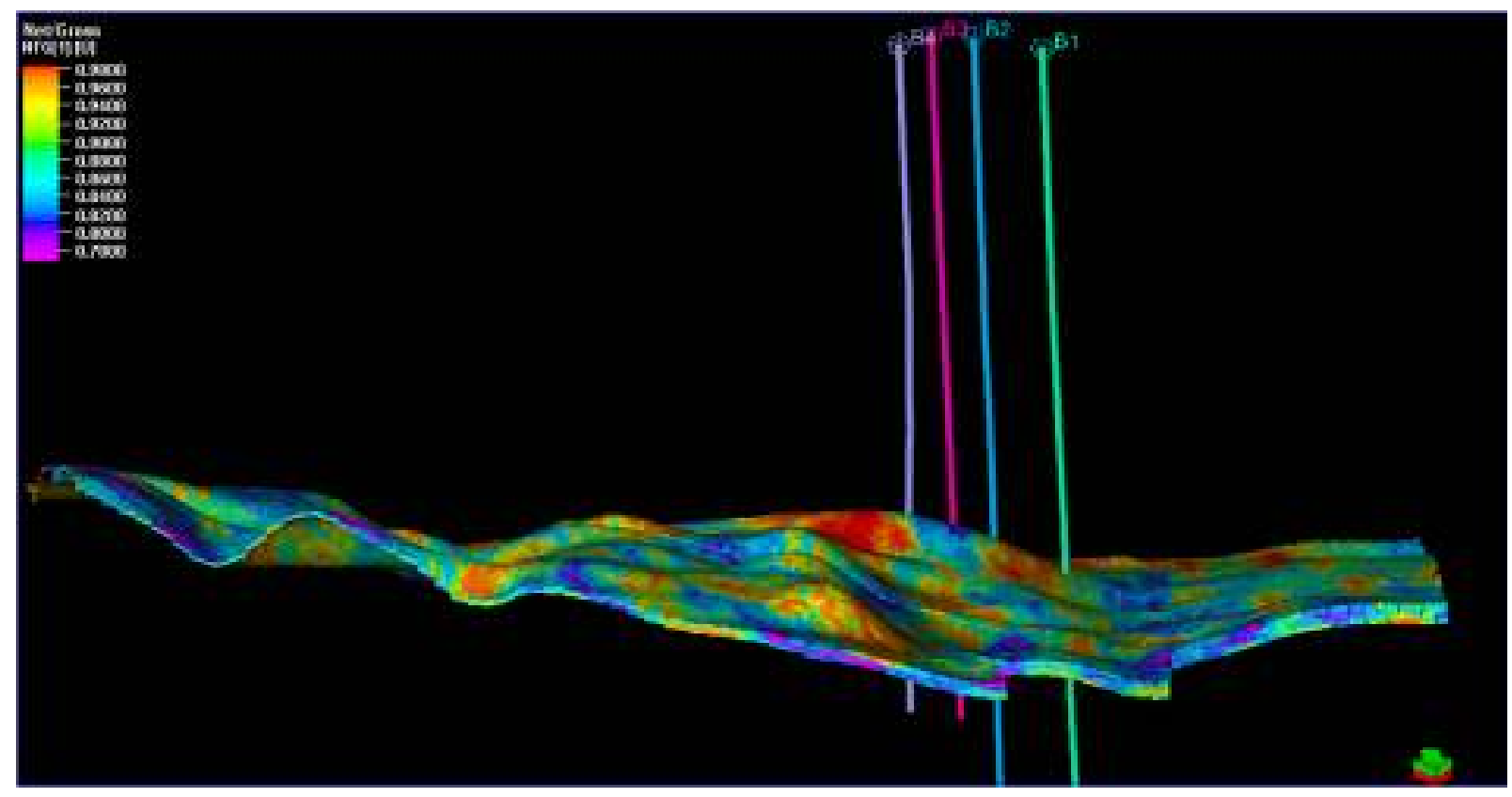

Fig. 7: Petrophysical model of Godwin reservoir (Net to Gross Model)

(i.e., sand and shale) over the Godwin reservoir is as shown in Fig. 6. It was observed that the reservoir has moderate to high sand distribution. A reasonable amount of sand bodies were also observed around the prospective structure at the far Eastern end of the reservoir and the regional deposition is assumed to be in NW-SE direction.

The Net to Gross mode generated for Godwin reservoir as shown in Fig. 7 revealed a net to gross ranging from $(0.77-0.97)$ across the reservoir which means the reservoir has an averagely high net to gross value.

The 3D perspective view of the porosity model generated for Godwin reservoir is as shown in Fig. 8. The porosity model shows porosity ranging from $(0.20$ 0.30 ) across the reservoir. This also indicates a good porosity according to literature of Niger Delta reservoir porosity.

Figure 9 shows a 3D perspective view of the permeability model of Godwin reservoir. The model 


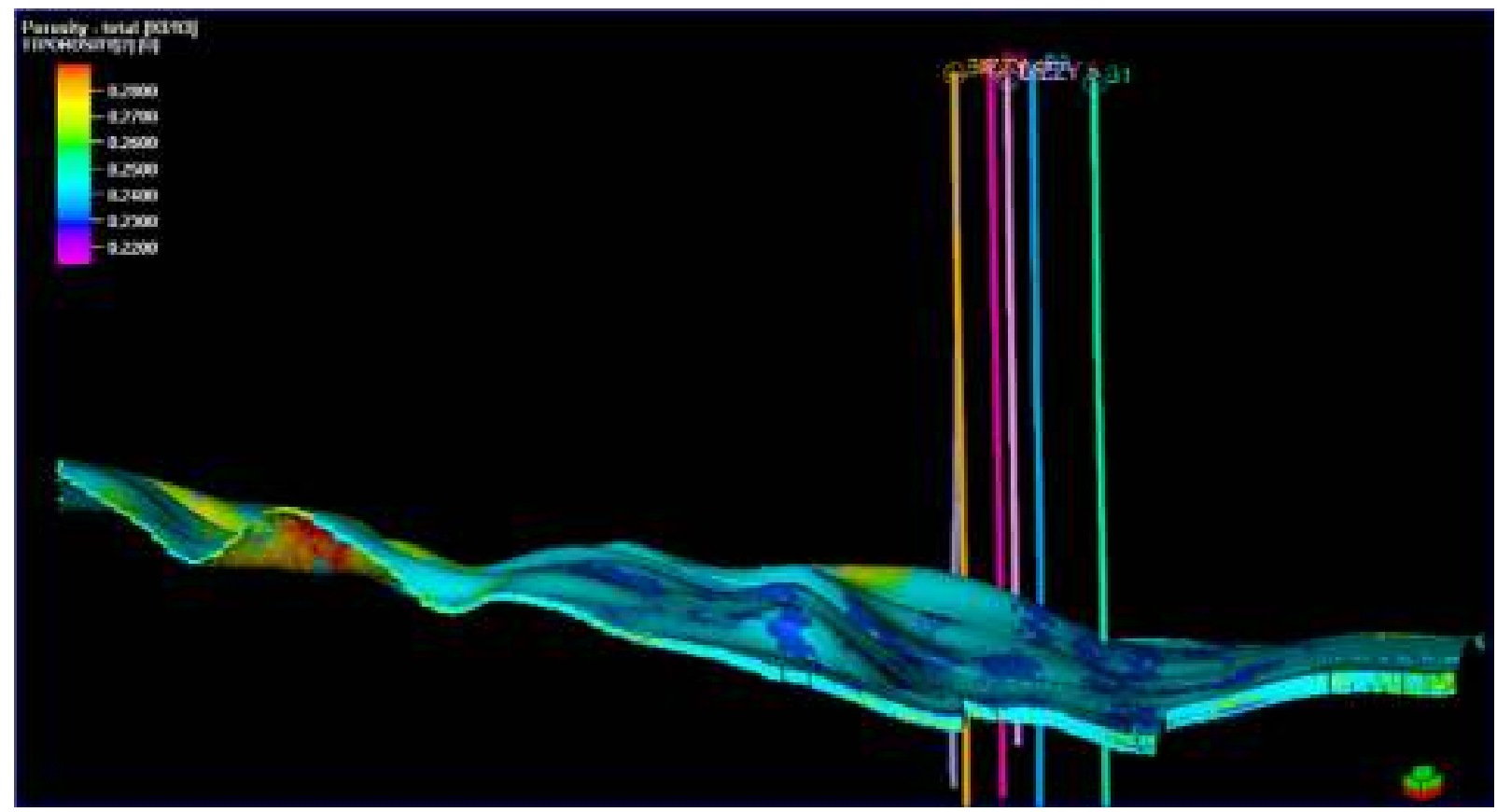

Fig. 8: Petrophysical model of Godwin reservoir (Porosity Model)

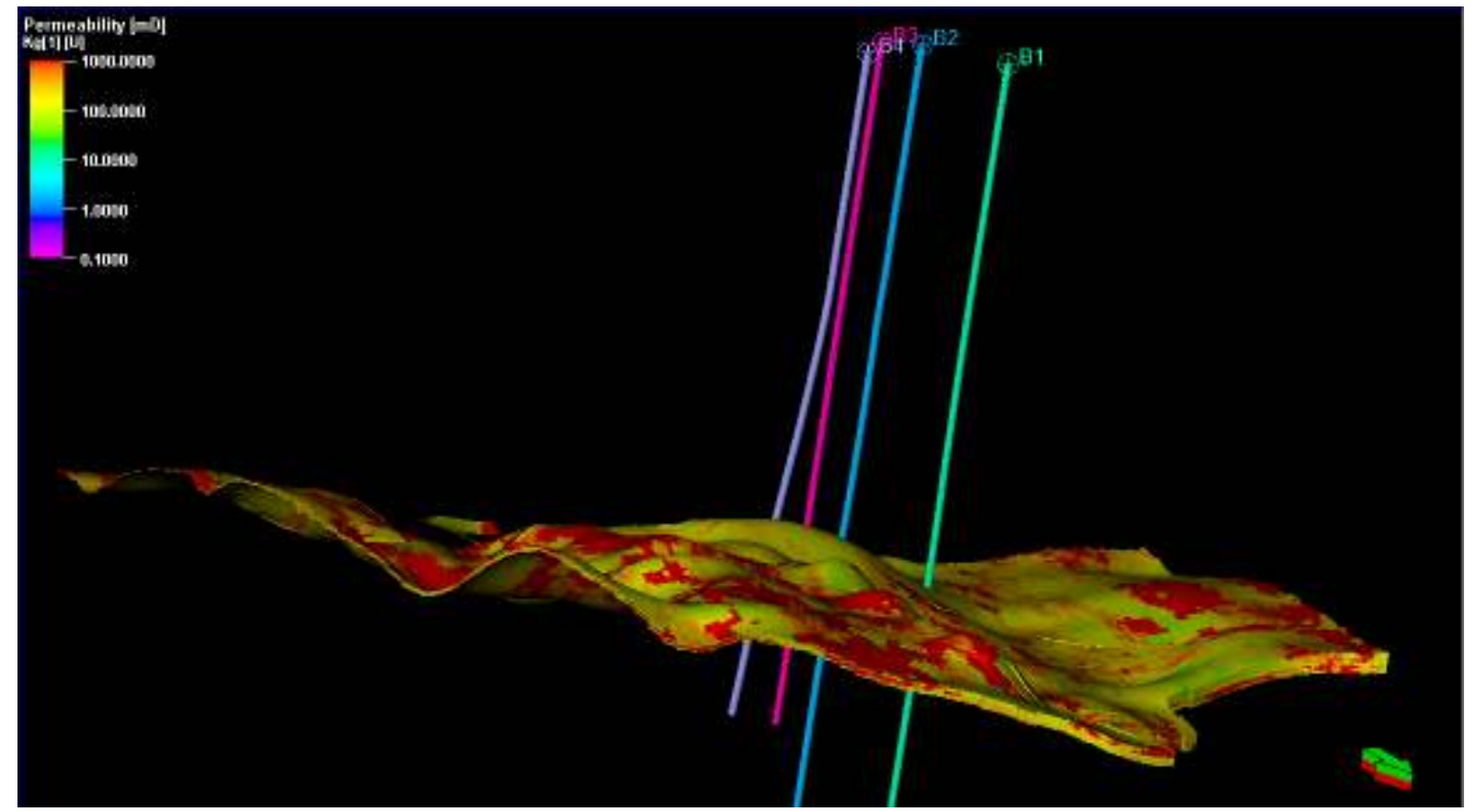

Fig. 9: Petrophysical model of Godwin reservoir (Permeability Model)

reveals that water saturation distribution of the Goodwin reservoir varies from $63 \mathrm{mD}$ to $6153 \mathrm{mD}$. This mean the reservoir has a moderate to very good permeability range that will enhance effective extraction of hydrocarbon during production. The water saturation model for Godwin reservoir is shown in Fig. 10 with low values around the structural high suggesting a corresponding high hydrocarbon saturation. However, there are areas that are saturated with water on the reservoir as revealed by the model.

\section{CONCLUSION}

From the results of the well log interpretation, petrophysical analysis and the geological reservoir modelling, Godwin reservoir showed good distribution 


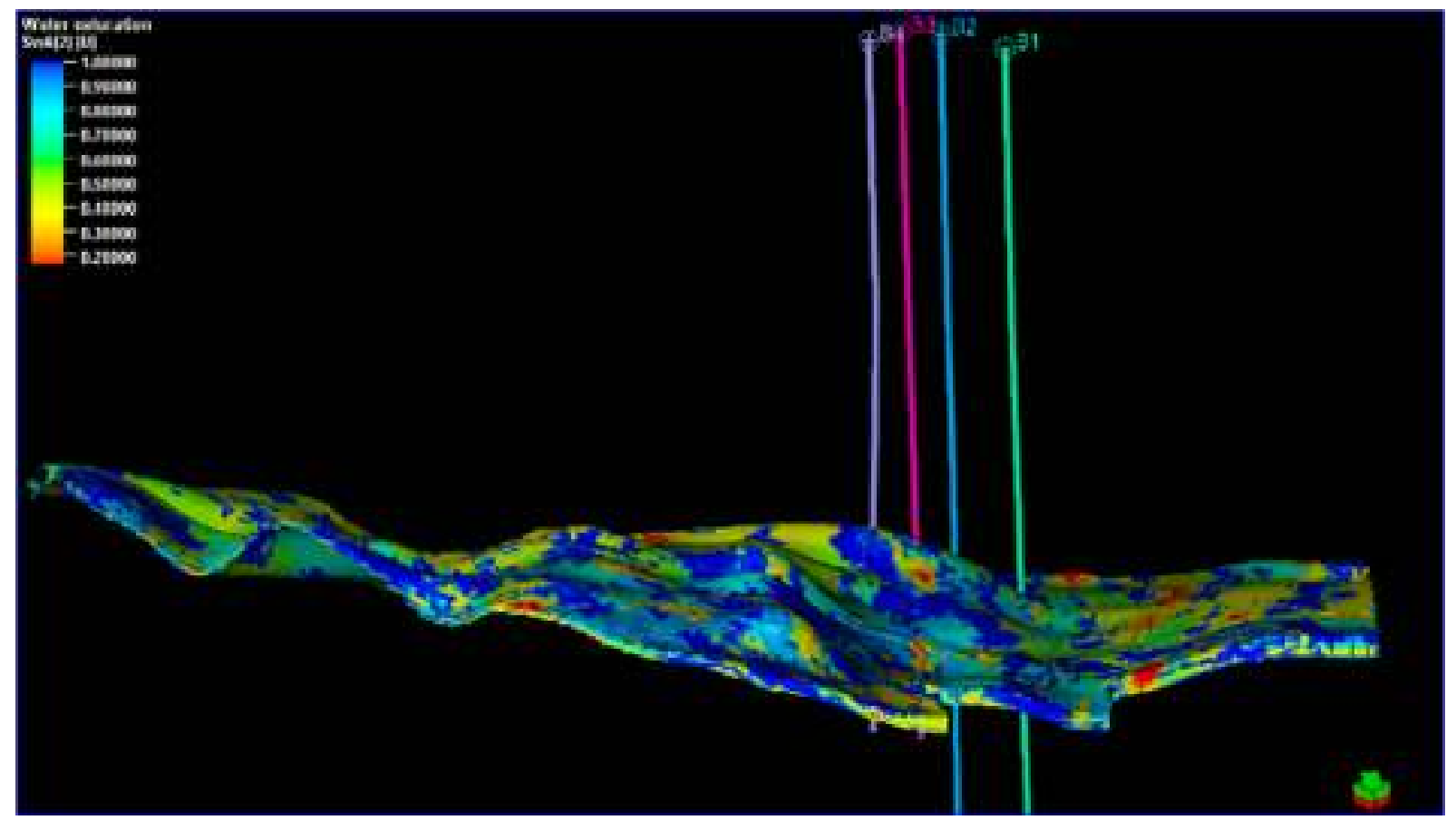

Fig. 10: Petrophysical model of Godwin reservoir (Water Saturation Model)

of reservoir properties and there are other drillable areas (prospects) from which hydrocarbon can be extracted. The structural high visible at the eastern ends of the structural maps calls for extensive data acquisitions around the area to further validate the prospective structure. This research study has shown that the application of geostatistical tools for 3D spatial distribution of reservoir parameters is a veritable tool for identifying new prospects.

\section{REFERENCES}

Clevis, Q., G.E. Tucker, S.T. Lancaster, A. Desitter, N. Gasparini and G. Lock, 2006. A simple algorithm for the mapping of TIN data onto a static grid: Applied to the stratigraphic simulation of river meander deposits. Comput. Geosci., 32(06): 749766.

Dubrule, O., 1998. Geostatistics in Petroleum Geology. AAPG, Continuing Education Course Note Series No. 38, Tulsa, Oklahoma, USA, ISBN: 9780891811879.

Ethier, V.G., 1975. Application of Markov analysis to the banff formation (Mississippian), Alberta. J. Int. Accoc. Math. Geol., 7: 47-61.

Evamy, B.D., J. Harembourne, P. Kamerling, W.A. Knaap, F.A. Molley and P.H. Rowlands, 1978. Hydrocarbon habitat of Tertiary Niger Delta. AAPG Bull., 62: 1-39.

Haldersen, H.H. and E. Dasleth, 1993. Challenges in reservoir characterization: GEOHORIZONS. AAPG Bull., 77(4): 541-551.
Hennings, P.H., J.E. Oslon and L.B. Thompson, 2000. Combining outcrop data and three-dimensional structural models to characterize fractured reservoirs: An example from Wyoming. AAPG Bull., 84(6): 830-849.

Jackson, M.D., S. Yoshida, A.H. Muggeridge and H.D. Johnson, 2005. Three-dimensional reservoir characterization and flow simulation of heterolithic tidal sandstones. AAPG Bull., 89(4): 507-528.

Labourdette, R., J. Poncet, J. Seguin, F. Temple, J. Hegre and A. Irving, 2006. Three-dimensional modelling of stacked turbidite channels inWest Africa: Impact on dynamic reservoir simulations. Petrol. Geosci., 12(4): 335-345.

Lake, I.W., H.B. Carrol and T.C. Wesson. 1991. Reservoir Characterization. Academic Press, San Diego.

Liz, T., 2009. Simulation tools maximize accuracy of 3D reservoir models. The American Oil and Gas Reporter.

Lucia, F.J. and G.E. Fogg, 1990. Geologic/stochastic mapping of heterogeneity in a carbonate reservoir. J. Petrol. Technol., 42(1): 1298-1303.

Masaferro, J.L., M., Bulnes, J. Poblet and N. Casson, 2003. Kinematic evolution and fracture prediction of the Valle Morado structure inferred from 3-D seismic data, Salta Province, northwest Argentina. AAPG Bull., 87: 1083-1104.

Mitra, S. and W. Leslie, 2003. Three-dimensional structural model of the Rhourde el Baguel field, Algeria. AAPG Bull., 87(02): 231-250. 
Mitra, S., J.A.D. Gonzalez, J.G. Hernandez, S.H. Garcia and S. Banerjee, 2006. Structural geometry and evolution of the $\mathrm{Ku}$, Zaap, and Maloob structures, Campeche Bay, Mexico. AAPG Bull., 90(10): 1565-1584.

Patrick, D.D., G.S. Soreghan and J.P. Castagna, 2002. Outcrop-based reservoir characterization: A composite phylloid-Algal Mound, Western Orogrande basin (New Mexico). AAPG Bull., 86(5): 799-795.

Vistelius, A.B., 1992. Principles of Mathematical Geology. 1st Edn., Published by Springer. ISBN10: 9401053030 .
Wong, P.M., 2003. A novel technique for modeling fracture intensity: A case study from the Pinedale anticline in Wyoming. AAPG Bull., 87(11): 17171727.

Worthington, P.F., 1991. Reservoir Characterization at the Mesoscopic Scale. In: Lake, I.W., H.B. Carrol and T.C. Wesson (Eds.), Reservoir Characterization. Academic Press, Waltham, 2: 123-165. 